University of Nebraska - Lincoln

DigitalCommons@University of Nebraska - Lincoln

June 1975

\title{
Stages in Corporate Stability and the Risks of Corporate Failure
}

Richard C. Edwards

redwards1@unl.edu

Follow this and additional works at: https://digitalcommons.unl.edu/econfacpub

Part of the Economics Commons

Edwards, Richard C., "Stages in Corporate Stability and the Risks of Corporate Failure" (1975). Economics Department Faculty Publications. 6.

https://digitalcommons.unl.edu/econfacpub/6

This Article is brought to you for free and open access by the Economics Department at DigitalCommons@University of Nebraska - Lincoln. It has been accepted for inclusion in Economics Department Faculty Publications by an authorized administrator of DigitalCommons@University of Nebraska - Lincoln. 


\section{Stages in Corporate Stability and the Risks of Corporate Failure}

$\mathbf{F}$ EW would deny that the U.S. economy is today dominated by huge corporations. Much recent writing has proposed that these corporations form a stable and monopolistic (or oligopolistic) "core" around which a more competitive "peripheral" sector exists. Firms in the core are said to be "eternal," while firms in the periphery demonstrate the mortality and high turnover expected in competitive industries. ${ }^{1}$ In another context, Paul Baran and Paul Sweezy emphasized the permanence of big corporations when they noted:

The real capitalist today is not the individual businessman but the corporation. ... The giant corporation of today is an engine for maximizing profits and accumulating capital to at least as great an extent as the individual enterprise of an earlier period. But it is not merely an enlarged and institutionalized version of the personal capitalist. There are major differences between these types of business enterprise, and at least two of them are of key importance to a general theory of monopoly capitalism: the corporation has a longer time horizon than the individual capitalist, and it is a more rational calculator. ${ }^{2}$

From an historical perspective, however, it appears to be an open question whether big corporations are long-lived or whether they tend to be "paper tigers" of glorious but relatively short longevity. For example, the most influential study, A. D. H. Kaplan's Big Enterprise in a Competitive System, finds that only thirty-one of the one hundred largest (by assets) corporations in 1909 would qualify for the 1960 "top one hundred" list. Although no absolute criterion exists for what would constitute "high" or "low" turnover, Kaplan's figures hardly impress one as evidence of a "stable" core. Apparently

Many of the ideas in this paper were worked out jointly with David Gordon and Michael Reich. I would like to thank Jane Baird and Winnie Edwards for their research help and an anonymous referee for suggestions.

1 See, for example, Robert Averitt, The Dual Economy: The Dynamics of American Industry Structure (New York: W. W. Norton, 1968); J. K. Galbraith, Economics and the Public Purpose (New York: Houghton Mifflin, 1972); James O'Connor, The Fiscal Crisis of the State (New York: St. Martin's Press, 1973); and Richard Edwards, David Gordon, and Michael Reich, "Labor Market Segmentation in American Capitalism" (mimeo).

2 Paul Baran and Paul Sweezy, Monopoly Capital (New York: Monthly Review Press, 1966), pp. 43, 47. 
Forbes magazine is correct in asserting that the "corporate eminence is located on a slippery slope."

This article focuses on the issue of corporate stability. I concentrate rather narrowly on the data on turnover and longevity of the biggest U.S. corporations in order to show that big business has passed through two quite different phases. The initial period of consolidation and transition (roughly 1890 to 1920 ) was a time of considerable instability for big corporations. But by the early twentiescertainly by 1923 - the system had "stabilized," and relatively little change has occurred since then.

\section{SOURCES OF EVIDENCE ON CORPORATE STABILITY}

The conclusion that big corporations lead precarious lives is well entrenched in the historical literature. This conclusion exists in somewhat surprising contrast to prevailing notions about present corporate structure. For example, critics of J. K. Galbraith (or Baran and Sweezy or Berle and Means) often argue that big corporations are less powerful and more constrained by markets than Galbraith asserts, but the critics rarely maintain that the giants are not durable.

Yet such appears to be the historical consensus. Several studies have appeared which attempt to trace the fortunes of big corporations since the merger movement at the turn of the century. ${ }^{3}$ Gen-

3 One of the earliest works was John Moody's The Truth about the Trusts (New York: Moody Publishing Co., 1904); A. A. Berle and Gardiner C. Means, The Modern Corporation and Private Property (New York: Macmillan Co., 1932) presented the first time series; recent work has been spurred by A. D. H. Kaplan's Big Enterprise in a Competitive System (Washington, D.C.: The Brookings Institution, 1954; revised edition, 1964) and the annual (since 1956) appearance of the Fortune " 500 " lists. Other studies are Norman Collins and Lee Preston, "The Size Structure of the Largest Industrial Firms, 1908-1958," American Economic Review (December 1961); Seymour Friedland, "Turnover and Growth of the 50 Largest Industrial Firms, 1906-1950," Review of Economics and Statistics (February 1957); Thomas R. Navin, "The 500 Largest Industrials in 1917," Business History Review (Autumn 1970); "Management," Forbes Magazine (September 15, 1967); David Mermelstein, "Large Industrial Corporations and Asset Shares," American Economic Review (September 1969); and Alfred D. Chandler, Jr., "The Structure of American Industry in the Twentieth Century: A Historical Overview," Business History Review, XLIII (Autumn 1969).

Most authors have not felt compelled to offer a justification for focussing on the largest corporations, provoking George Stigler to remark that "the statistical universe of the hundred or two hundred largest corporations is inappropriate to studies of monopoly and competition. ..." in "The Statistics of Monopoly and Merger," Journal of Political Economy (February 1956). Most authors, especially Kaplan, intend their studies to be relevant to the monopoly issue on the assumption that high turnover is a sufficient condition for the existence of competition. David Mermelstein, among others, has attempted to be more explicit in relating a corporation's overall size to its power, which presumably affects its exercise of power in product markets. 
erally these studies probe the meager historical sources to develop lists of the top one hundred (or fifty or five hundred) industrial corporations, for a series of benchmark years at roughly decade intervals. A. D. H. Kaplan, for example, presented lists of the largest (by asset size) one hundred industrial firms for 1909, 1919, $1929,1935,1948$, and, in the revised edition, 1960. The data come primarily from such reference works as Standard and Poor's and Moody's manuals. "Stability" is measured by the number of firms that survive from earlier to later lists.

Kaplan found that of the top one hundred firms in 1909, only thirty-one firms remained among the top one hundred in 1960. Norman Collins and Lee Preston, after revising Kaplan's lists somewhat, report thirty-six firms which were in the top one hundred in both 1909 and 1958. Seymour Friedland prepared a list very similar to Kaplan's but restricted his attention to the top fifty in 1906. He found that only eighteen of the original firms survived to the 1950 list. Similarly, Forbes magazine investigated turnover among the top one hundred industrials between 1917 and 1967 and found that forty-five on the earlier list survived to the 1967 list. Finally, Thomas Navin prepared a list of the top five hundred industrials in 1917. According to his list, forty-two of the top one hundred firms (by assets) in 1917 continued to be large enough to rank in the top one hundred (by sales) on Fortune's 1967 list. Kaplan and Forbes concluded that turnover was "high," while Collins and Preston and Friedland decided that size was indeed related to "stability," although clearly the evidence used is quite similar. Navin contented himself with a careful presentation of the evidence, adding only the astute observation that turnover between 1917 and 1967 among the largest forty firms seemed substantially less than among the remaining four hundred and sixty.

These studies provide the basis for a consensus on the turnover issue. Apparently of the top one hundred firms in the opening decades of the century, roughly thirty to forty-five would appear on the list fifty years later. Whether or not that figure is large seems to de-

See "Large Industrial Corporations and Asset Shares: Reply," American Economic Review (March 1971). Nevertheless, for studies of concentration per se, industry studies would appear to be more appropriate. The focus here is directly on corporate power, for which the largest corporations are precisely the correct "statistical universe," though of course there is nothing magical about any particular cutoff point (e.g., the top 100). 
pend on one's inclinations, but it does not provide much basis for viewing the big corporation as an "eternal life" institution.

The issue of corporate power and longevity is not quite so simple, however. The work as it now stands can be faulted on several counts. ${ }^{4}$ First, the focus on gross turnover fails to distinguish among entrants and exits resulting from mergers, court-ordered dissolutions, or "normal" growth or decline of companies. For example, if two firms on the top one hundred list in 1919 merged to form a new company, "turnover" would be increased (two exits, one entrant) yet economic power would have become more concentrated. Second, artificial distinctions among categories also create "turnover" where real industrial power continues: Cities Service Co. (now Citgo), although a large enterprise before 1954, was classified as a utility; in that year it disposed of its remaining domestic utility holdings, thus

4 All of the studies concerning "Big Business" take the size of the firm's assets as the means of determining "bigness." The choice of assets as basis for categorization represents an unfortunate but necessary compromise. Whether or not it is theoretically the appropriate variable, its measurement is sufficiently difficult to cause unease. The assets of a firm pass through a market-and hence are properly valued-only when the firm is actually sold. At all other points, the asset values must be estimated. In this respect, annual sales (on which the Fortune list is based), number of employees, or value added would provide a much more accurate measurement.

The "errors in variables" problem for assets can be simply illustrated. For extractive industries, a considerable part of each firm's assets consist of unmined minerals, oil, coal, etc. still in the ground. Not only is it difficult to measure the quantity of such stores, the value of those quantities obviously depends on such variables as the future costs of extracting them and future product prices. Thus none of the consequent estimates can be said to be based at all directly on market valuesthe only "true" test. A different form of the problem emerges most dramatically from the steel industry. Early estimates of the assets of U.S. Steel rely on the gross stock capitalization at its formation. Yet the merger of Carnegie Steel and several other firms to form U.S. Steel resulted in the new firm having stock worth, at face value, more than twice the combined assets of the merged companies. Some increase in the capitalized value of future earnings could legitimately be expected as a result of cost savings, increased monopoly power, and the like, and the larger value was what the J. P. Morgan promoters estimated the stock market would bear. The subsequent decline of the stock value indicated their mistake, but it does not help the historian attempting to calculate asset values.

It might be argued that the value of the firm can be estimated from the stock prices of publicly traded shares, which prices should reflect the present value of the discounted stream of expected future net earnings. Even if this hypothesis on stock price behavior is accepted, two considerations argue against its application: (1) for many firms early in the century, the shares were not publicly traded, so this method does not provide a general approach; and (2) for many firms whose shares were traded, large blocks of stock were held off the market by individual families (e.g., the Mellons with Gulf stock), upwardly biasing the market price of those shares traded.

These methodological problems are not trivial, but the meagerness of historical data sources allows no alternative. Evidence for asset size, though scanty, inaccurate, and not always comparable, exists; evidence for other variables does not. 
"enabling" it to be classified as an industrial and thereby becoming a recent "entrant." Third, an extremely restrictive standard was applied to determine when a "new" company had emerged: for example, Kaplan declares that the "Maxwell Motor Co. was the predecessor of Chrysler Corp.," yet he and others list Maxwell as an exit and Chrysler as an entrant.

Fourth, there is a basic question as to whether turnover among the top one hundred constitutes an adequate measure of "stability." As Collins and Preston note, new entrants are rarely new to the economy, and exits, except those by merger or liquidation, rarely disappear. Moreover, most of the "action" in turnover is concentrated near the cutoff point: of all two hundred and forty-six entrants and exits between their six benchmark years listed by Collins and Preston, one hundred and nine (forty-four percent) were ranked eighty-one to one hundred in their last or first year of appearance.

Fifth, the choice of a base period seems to influence substantially the conclusions obtained. Kaplan's data provide an illustration of this base-year sensitivity. According to his work, only thirty-one firms in the top one hundred in 1909 survive to the 1960 list; sixtynine fail to do so. But of these sixty-nine failures, fully thirty-eight (fifty-five percent) had moved off the list by 1919 and never reappeared. If the sixty-nine failures had been spaced evenly over the fifty-one-year span, only 13.5 would have been expected to fail by 1919 versus the thirty-eight that actually failed. Appendix Table I indicates that the rate of exits in the period 1909-1919 was never less than twice, and usually many times greater than in succeeding periods.

If choice of the base period makes a significant difference, that choice should not be made arbitrarily but rather derive from an interpretation of American economic development. The authors of previous studies place the base before the First World War. Kaplan chose 1909; Collins and Preston and others (for example, Mermelstein; Chandler) followed his lead. Friedland chose 1906. Forbes chose 1917 because it was the year the magazine was founded. Navin accepted 1917, but indicates he would have preferred an earlier year. Yet none of these authors provides a plausible historical justification for his choice of base year.

5 Kaplan, Big Enterprise, p. 152-153, notes 13 and 37. On the basis of the "majority of assets" rule given below, Dodge is here treated as parent of the modern Chrysler Corporation and Maxwell is counted as an "exit;" see Appendix Table V. 
Finally, focusing on industrials alone underemphasizes the extent of the consolidation of power achieved by the early twenties. The exclusion of public utilities, railroads, merchandising firms, banks, and insurance companies is particularly serious.

In order to minimize these problems, I adopt the following procedures when considering the data. First, I separate the "exits" by whether they are due to mergers, liquidations, or simple failures to grow. Second, no firm that appears on an earlier list will be excluded from a later list because it is "reclassified." Although excluding reclassified firms might be appropriate if the category "industrials" had a strict and economically meaningful boundary, which it does not, it is clearly unjustified in any attempt to understand the concentration of economic power. Third, I consider a newly-named company as simply a "successor" and not a new company if the assets of the acquired company constitute fifty percent or more of the "new" company. Fourth, I look beyond gross turnover; I not only consider the strict criterion of whether a firm in an earlier year (for example, 1919) has survived to the top one hundred in a later year (for example, 1969), but also the more sensible criterion of whether it survives as a large and powerful firm-for example, whether it has been able to maintain the real value of its assets in the later year. I also analyze the category of failures: those firms that go bankrupt, enter receivership, or fail to maintain their capital. Fifth, rather than casually choose a base, I hypothesize stages which justify the treatment of the 1890-1920 period as separate from the period which began in the early twenties. Finally, I analyze "industrials" separately so that my results can be compared directly with earlier work, but I also present some evidence for turnover among railroad, utility, merchandising, banking, and insurance companies as well.

The issue here resolves itself into two parts. First, was there (relatively) great change in the status of big industrial corporations between the turn-of-the-century merger movement and the end of the war and a constrastingly great (relative) stability between the early twenties and the present? ${ }^{8}$ While there still is no absolute cri-

- Since specific points in time are required for the analysis, the earlier period is defined as 1903 to 1919 , the latter as 1919 to 1969 . Operationally I take 1919 as an acceptable compromise for the start of the latter period in order that my results can be compared directly with earlier work, but some later year, perhaps 1923, would be a better cutoff point (see footnote 8 ). Since these are continuous economic processes, an "exact" cutoff point is not possible nor important. 
terion for "high" or "low" stability, the comparison between periods, when adjusted to account for the difference between the lengths of the periods, provides one yardstick. Second, was the stability achieved by the early twenties generalized throughout the economy or restricted to a few sectors?

\section{INSTABIITY (1903-1919) VERSUS STABILITY (1919-1969)}

Data for the earlier period are sketchy and much less accurate than for the later period. John Moody, the major source for all these studies, did not begin publishing data on industrials until 1900, and understandably coverage during the early years was less than comprehensive. Nonetheless, the pattern seems pretty clear.

Data for the early period derive from several sources. ${ }^{7}$ First, we have the lists prepared by Kaplan and by Collins and Preston for 1909. Second, for 1903 I have prepared a list (Appendix Table IV) of the one hundred largest industrial firms listed in Moody's manual for that year. Finally, for the end of the period I use two sets of data. For gross turnover, I use the Kaplan and Collins and Preston lists for the top one hundred in 1919. For all other analysis, I rely on Navin's 1917 data. Although 1919 or 1920 would have been a better end-date, the comprehensiveness and accuracy of Navin's list more than compensate for the two year lapse.

For the later period, we have lists provided by Kaplan (19191960), Collins and Preston (1919-1958), Navin (1917-1967), Forbes (1917-1967), and a comprehensive list (1919-1969) I have compiled from all these sources, cross-checked with the Moody manuals and other sources.

I consider successively three comparisons of the two periods. First, I look at gross turnover-simply the movement of firms in an earlier (1903, for example) list of the top one hundred industrials out of a later list (for example, out of the 1919 list). Interestingly, comparison of this crude measure for the pre- and post-1919 periods fairly accurately indicates the differences between the two periods although it overstates turnover in both. Second, I consider a different

7 These are not, strictly speaking, entirely independent sources. All begin with the Moody's manuals. However, each supplements this basic source with investigation of company records and reports, correspondence with surviving firms, corporate histories, and similar material. Moreover, each uses a slightly different definition for what constitutes "industrial" firms. Finally, treatment of assets and estimates differ somewhat. 
and "weaker" criterion of turnover: I first take the assets of the smallest firm (that is, that listed one hundred) in an earlier list; I then inflate this figure by the ratio of prices in the end and base periods, so that the new figure represents the constant-dollar analog for the asset cutoff of the base period. Firms are listed as "survivors" if during the period they maintained assets equal or greater in constant-dollars than the smallest firm in the base year. Firms that were acquired, were dissolved, or failed to maintain their assets are listed as exits. Third, I consider the types of exits from the "weak" criterion list and the relative success of the survivors.

Gross turnover is given in Table 1. As indicated in column (4), the

TABLE 1

GROSS TURNOVERS-TOP 100

\begin{tabular}{|c|c|c|c|c|}
\hline & (1) & (2) & (3) & $\begin{array}{c}\text { (4) } \\
\text { Rate of Exits } \\
\text { Per } 100 \text { Firms } \\
\text { Per Year }\end{array}$ \\
\hline $\begin{array}{l}\text { 1903-1919 } \\
\text { (Edwards) }\end{array}$ & 45 & 55 & 0 & $3.4^{a}$ \\
\hline $\begin{array}{l}\text { 1909-1919 } \\
\text { (Kaplan) } \\
1909-1919\end{array}$ & 61 & 39 & 0 & $3.9 \mathrm{a}$ \\
\hline $\begin{array}{l}\text { (Collins \& Preston) } \\
1917-1967\end{array}$ & 61 & 39 & 0 & $3.9 \mathrm{a}$ \\
\hline $\begin{array}{l}\text { (Navin) } \\
1917-1967\end{array}$ & 47 & 54 & $\mathbf{0}$ & $1.1 \mathrm{e}$ \\
\hline & 47 & 51 & $2^{\mathbf{b}}$ & $1.0^{c}$ \\
\hline $\begin{array}{l}\text { (Kaplan) } \\
1919-1958\end{array}$ & 53 & 45 & $2^{b}$ & $1.1 \mathrm{c}$ \\
\hline $\begin{array}{l}\text { (Collins \& Preston) } \\
\text { 1919-1969 }\end{array}$ & 52 & 45 & $\mathbf{3}^{\mathbf{b}}$ & $1.2^{\mathrm{c}}$ \\
\hline (Edwards) & 51 & 59 & $\mathbf{0}$ & $1.0 \mathrm{c}$ \\
\hline
\end{tabular}

a These figures can be corrected for the Standard Oil and American Tobacco dissolutions, which created 10 new entrants to the top 100 list by 1919 , by defining "survivors" as being in the top 110 according to Navin's 1917 list; no change occurs in the Edwards list and only two more firms survive in each of Kaplan's and Collins and Preston's lists.

b Excluded as inappropriate: Great Northern Iron Ore Properties (excluded from Forbes, Kaplan, and Collins and Preston lists) was in fact simply a trust to collect royalties from iron ore lands owned by the James Hill family; Mexican Petroleum (excluded from Forbes list) was owned by Pan-American Petroleum, which also appears on list; Magnolia Petroleum (excluded from Kaplan and Collins and Preston lists) controlled by Standard Oil of N.Y., which acquired Magnolia starting in 1918 (see N.Y. Times, Feb. 2, 1918, p. 15, and Nov. 10, 1925, p. 33). American Express (excluded from Collins and Preston list) was and is primarily a financial corporation.

c Adjusted for base different from top 100 firms (i.e., Navin base 101; Forbes 98; Kaplan 98; Collins and Preston 97; Edwards 110).

Source: See text and footnote 3. 
TABLE 2

"WEAK" TURNOVER-TOP 100a

\begin{tabular}{|c|c|c|c|c|}
\hline & Survivors & Failures & $\begin{array}{l}\text { Excluded Due } \\
\text { to Reclassifi- } \\
\text { cation, etc. }\end{array}$ & $\begin{array}{l}\text { Rate of Failure } \\
\text { Per } 100 \text { Top } \\
\text { Firms Per Year }\end{array}$ \\
\hline $\begin{array}{l}\text { 1903-1917 } \\
\text { (Edwards)e }\end{array}$ & 66 & 34 & 0 & 2.4 \\
\hline $\begin{array}{l}\text { 1909-1917 } \\
\text { (Kaplan)d }\end{array}$ & 65 & 35 & 0 & 4.4 \\
\hline $\begin{array}{l}\text { 1909-1917 } \\
\text { (Collins \& Preston) d }\end{array}$ & 65 & 35 & 0 & 4.4 \\
\hline $\begin{array}{l}\text { 1917-1967 } \\
\text { (Navin)e }\end{array}$ & 69 & 32 & 0 & $0.6^{\mathrm{b}}$ \\
\hline $\begin{array}{l}\text { 1917-1967 } \\
\text { (Forbes)f }\end{array}$ & 67 & 31 & 2 & $0.6^{b}$ \\
\hline $\begin{array}{l}1919-1960 \\
(\text { Kaplan }) \mathrm{g}\end{array}$ & 73 & 25 & 2 & $0.6^{b}$ \\
\hline (Collins \& Preston $)^{\mathrm{h}}$ & 72 & 25 & 3 & $0.6^{b}$ \\
\hline $\begin{array}{l}\text { 1919-1969 } \\
\text { (Edwards)! }\end{array}$ & 70 & 40 & 0 & $0.7 \mathrm{~b}$ \\
\hline
\end{tabular}

all prices used in calculations given in Appendix Table VI.

b Adjusted for base different from top 100 firms (i.e., Navin base 101; Forbes 98; Kaplan 98; Collins and Preston 97; Edwards 110).

c Smallest firm 1903 had assets of $\$ 15$ million; price change $=+97 \%$; firms are survivors if 1917 assets exceed $\$ 29.6$ million.

d Smallest firm 1909 according to both Kaplan and Collins and Preston had assets of $\$ 25$ million; price change $=+74 \%$; firms are survivors if 1917 assets exceed $\$ 43.5$ million.

- Smallest firm in 1917 according to Navin had assets of $\$ 50.0$ million; price change $=+65 \%$; firms are survivors if 1967 assets exceed $\$ 82.5$ million.

I Smallest firm in 1917 according to Forbes had assets of $\$ 54$ million; price change $=+65 \%$; firms are survivors if 1967 assets exceed $\$ 87.1$ million.

g Smallest firm in 1919 according to Kaplan had assets of $\$ 54$ million; price change $=+33 \%$; firms are survivors if 1960 assets exceed $\$ 71.8$ million.

h Smallest firm in 1919 according to Collins and Preston had assets of $\$ 60.5$ million; price change $=+33 \%$; firms are survivors if 1958 assets exceed $\$ 79.9$ million.

1 Smallest firm in 1919 according to Edwards had assets of $\$ 50.0$ million; price change $=+49 \%$; firm is survivor if 1969 assets exceed $\$ 89.5$ million.

Source: See text and footnote 3.

rate of exits per year is more than three times greater in the pre-1919 period than it is in the post-1919 period. Moreover, as note (a) indicates, these results do not reflect "spurious" turnover due to the 1911 Standard Oil and American Tobacco dissolutions.

Table 2 gives the number of survivors and failures on the "weak" turnover criterion. Firms listed as "failures" necessarily disappeared or suffered a decline in the real value of their assets; some listed as "survivors" also suffered a decline, but not sufficient to move them entirely out of the group. The rate of failures per one hundred firms 


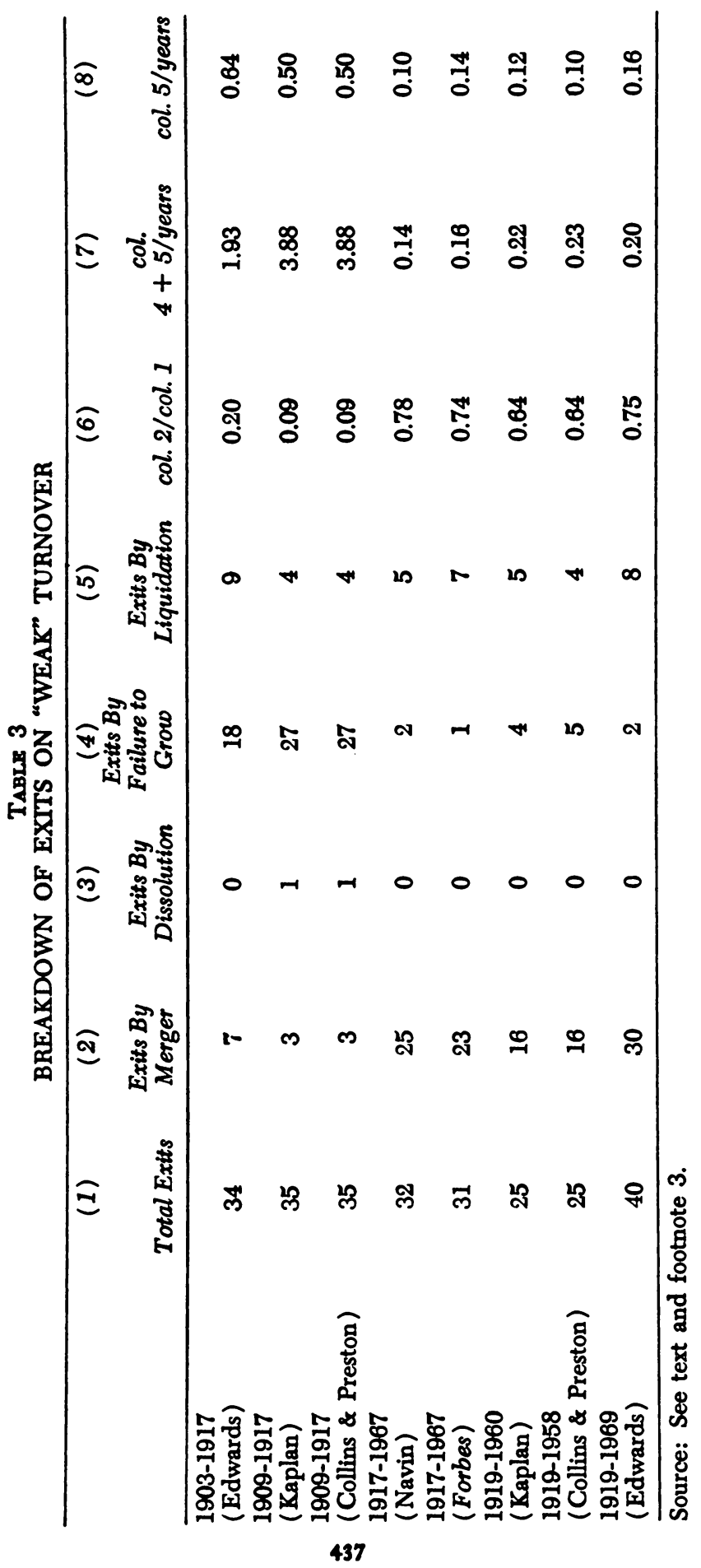


per year is again at the least three times as great $(2.4 / 0.7)$ in the pre-1917 as post-1919 period.

Table 3 gives the distribution of the failures listed in Table 2. As shown in column (6), in the pre-1917 period few exits were caused by firms disappearing through mergers (nine to twenty percent), whereas in the post-1917 period most (sixty-four to seventy-eight percent) were due to this cause. Mergers may reflect either a firm's weakness (and hence susceptibility to takeover) or strength (attractiveness of its earnings to the acquiring firm) or simply consolidation (for example, merger of three or more firms where no firm provided at least half of the assets of the consolidated company). Thus the category of "mergers" represents exits of both strong and weak companies, and little can be concluded about whether they are "successful" or "unsuccessful" companies.

On the other hand, exits caused by "failure to grow" and "liquidation" are unambiguous failures. As the last two columns show, firms failed far more frequently in the pre-1917 than in the post-1919 period-by at the least a factor of 8 (1.93/0.23).

Thus we can conclude, I believe, that the period from the 18981902 merger movement through the First World War was a period of relatively great instability compared to the post-war period. Moreover, the magnitudes themselves are important. In the earlier period, on the average two to four firms every year dropped below the minimum (constant dollar) assets of the smallest firm in the top one hundred in the base year. In the later period, it took approximately five years for one firm to drop out of the group.

Table 4 gives the number of firms listed in 1903 and in 1919 which continued until 1917 or 1969 as independent firms. Even for those that remained independent throughout each (or both) of the periods, the 1903-1917' span was a time of considerable risk for big corporations-column (7) indicates that sixty-eight percent of the survivors suffered a decline in their real assets between 1903 and 1917, whereas only three percent of the survivors did so between 1919 and 1969. Moreover, this does not appear to be simply a price phenomenon: seventeen firms between 1903 and 1917 suffered declining asset values measured in current dollars, versus only one in the later period.

Finally, we can use Navin's list for another type of stability test. The top one hundred (or so) corporations in 1917 constituted true 


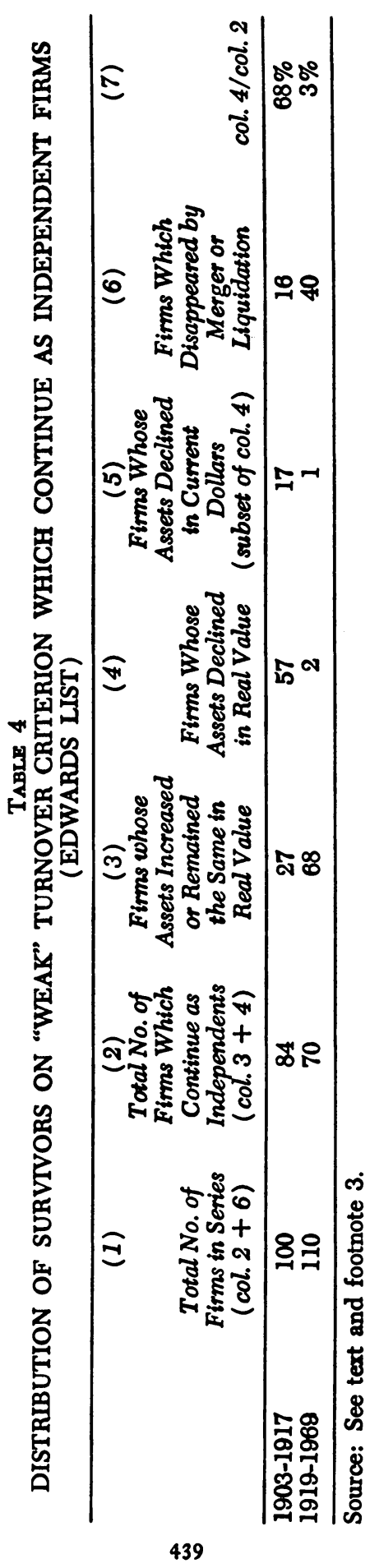


industrial "giants." They were generally integrated firms which had significant national market power, they had extensive political influence, and they obtained access to outside capital through the major capital markets. On the other hand, the bottom one hundred or two hundred firms in Navin's list of five hundred can only be seen as medium-sized firms; they were largely local or regional firms, their market power was usually minimal, their stocks were not widely traded, and their political power was minimal except through groups like employer's associations or the National Association of Manufacturers. As a consequence, their fates were also quite dissimilar: while ninety-five of the top one hundred firms escaped liquidation, only seventy-four of the firms listed four hundred and one to five hundred (one hundred and sixty of those listed three hundred and one to five hundred) escaped liquidation. The differences are significant (chi-square test) at the .001 levels. The big firms survive; medium-sized (and presumably small) firms face relatively high odds of failure. ${ }^{8}$

\section{ANTI-TRUST ACTIVITY}

In addition to the instability during the 1903-1919 period reflected in the turnover data, the anti-trust activities of the Federal government created great uncertainty. ${ }^{\circ}$ The first big case was the Northern Securities case, decided in 1904, which dissolved J. P. Morgan's railroad consolidation. In the following ten or so years, major antitrust suits were filed against Standard Oil, American Tobacco, International Harvester, U.S. Steel, Armour, Swift, American Sugar Refining-all among the top ten industrial corporations in 1909-as well as Aluminum Co. of America, General Electric, Corn Products Refining, duPont, and many other big firms. Standard Oil and American Tobacco were dissolved into thirty-four and sixteen parts, respectively. International Harvester, Corn Products, and duPont were forced to sell portions of their operations. Armour, Swift, and

8. The choice of 1919 rather than, say, 1923 as the starting point of the later period may result in a conservative bias to the evidence for differences in stability between the two periods: 7 of the $\mathbf{4 0}$ "failures" listed in the bottom row of Table 2 had already occurred by 1923 (see Appendix Table V); the rate of "failure" during these four years (1.75 failures per 100 top firms per year) is very close to halfway between the failure rates for the two periods on either side. This and, as an anonymous referee has suggested, other evidence (e.g., consolidation in the auto and steel industries) make 1922 or 1923 a more plausible cutoff date.

9 For a discussion of early anti-trust suits, see Eliot Jones, The Trust Problem in the United States (New York: Macmillan, 1921). 
the other big packing companies were forced to give up a mutually owned processing firm which had served as the agency for industry. wide collusion.

This unprecedented-and unrepeated-intervention by Federal agencies contributed to the uncertainty which surrounded the birth of big corporations. For example, U.S. Steel, when incorporated, controlled sixty-five percent of the steel market. For a time, it appeared that the government would define "unreasonable" restraint of trade as a situation which existed when, along with a number of other conditions, it could be shown that one firm controlled more than fifty percent of the market. U.S. Steel apparently decided to forego further consolidation, indeed even allow some erosion of its position, in order to escape anti-trust action. ${ }^{10}$ Big corporations did not find comfortable a situation in which the Anti-Trust Division could attack seven of the largest ten companies and actually force dismemberment of two.

COMPREHENSIVENESS OF THE POST-WORLD WAR I CONSOLIDATION

Turning now to the character of the capitalist consolidation achieved by the early 1920's, I attempt to demonstrate two assertions. First, I argue that the consolidation was achieved across most of the industrial categories. Firms which would continue to dominate those industries had emerged in industries processing or manufacturing food, tobacco, lumber and paper products, chemicals, petroleum, rubber, metals of all sorts, farm and construction machinery, electrical machinery, communications equipment, motor vehicles, and photographic equipment. With few exceptions-new industries like airplanes and computers and a few old ones like furniture, textiles, and drugs-the industrial structure which continues at present was set by 1920 .

Second, I attempt to show that the consolidation extended far beyond the usual category of "industrials" and in fact included transportation, utilities, insurance, banking, and to a lesser extent, merchandising. Firms in these areas that had achieved dominance by 1920 -again with a few exceptions-continue to dominate today.

Appendix Table II gives the distribution of those sixty-three firms

10 Ida Tarbell, The Life of Elbert H. Gary (New York: Appleton, 1926), pp. 257-258. Although the strategy proved to be in vain as far as avoiding prosecution, since U.S. Steel was prosecuted anyway, the company later obtained a favorable judgment. 
which survive to 1969 from the 1919 list, by industry category, along with their 1969 sales and 1969 rank in that industry. The data on industry and firm sales for 1919 do not exist, so no comparison between the beginning and end of the period is possible. The industries are divided by two- and three-digit SIC (Standard Industrial Classification) categories. Those categories in which no 1919 firms survive to 1969 have been grouped. Since the categories vary considerably in total sales (for example, some three-digit industries have more sales than some two-digit ones), the economic importance of each category differs but can be interpreted from the total industry figures for "value of shipments."

What is important in the table is the broad range of industries represented by 1919 firms. Although the biggest concentration occurs, as expected, in heavy industry (steel, non-ferrous metals, metal fabrication, petroleum, communication equipment, autos, chemicals, electrical and other industrial machinery, and farm and construction machinery), the post-war consolidation also included a series of lighter, consumer-oriented industries-meat packing, sugar, tobacco, and lumber and paper. ${ }^{11}$

Appendix Table III shows some of the consolidation which occurred in economic activities other than manufacturing and mining. Leaders which had emerged by 1919 continued in 1969 to dominate these other areas. The thirty-six telephone, gas, and electric companies listed as "large" in 1919 include eight of the top ten utility companies in 1969, as well as Cities Service Co., which, although now classified as an industrial, has sufficient assets to rank in the top ten. ${ }^{12}$ Of the top fifteen life insurance companies in 1917, fourteen continue among the top fifteen half a century later. The eight merchandising firms with 1919 assets greater than $\$ 20$ million include six of the largest ten merchandising firms by assets in 1969. Nine of the largest fifteen banks in 1922 continued among the top fifteen in 1967; five of the remaining six were acquired by banks now among the top fifteen. The list could go on, but what is important is the extent to which the industrial structure established by the end of the First World War has continued to the present.

The evidence reviewed above indicates that corporate capitalists

11 These results thus broadly conform to those given by Alfred Chandler in "The Structure of American Industry."

12 These data do not show the several large utility consolidations which were created in the 1920's nor the dissolutions under the Public Utility Holding Company of 1935. The persistence of the original companies is hence all the more remarkable. 
had achieved a quite widespread and enduring consolidation of their positions by 1919 . The industrial system which emerged out of this consolidation has been termed "monopoly capitalism"-a system in which the industrial center of the economy is dominated by large, oligopolistic, "eternal-life" corporations. ${ }^{13}$ The industrial structure might therefore be said to have passed through an earlier, unstable period and moved into the stable monopoly capitalist phase. For the remaining corporations, as the data reviewed above reveal, the risks of doing business in a "competitive" economy were considerably reduced. It was on the foundation of this stable industrial structure that the latest phase, that of multinationalism, developed and is still unfolding.

Richard C. Edwards, University of Massachusetts, Amherst

18 For a more complete discussion of monopoly capitalism see the sources cited in footnotes 1 and 2 above.

\section{Appendix TabLe I \\ FOR 100 LARGEST FIRMS IN 1909 THAT DID NOT APPEAR ON 1958 OR 1960 TOP 100 LISTS \\ EXPECTED AND ACTUAL EXITS \\ (corrected for length of period)}

(a) (b) (c)

1909-1919 1919-1929 1929-1935 1935-1948 1948-1960

\section{Kaplan's Data}

(1) Actual Number

(2) Expected Number

(3) Ratio of (1) to (2)

\section{8}

$13.5^{\mathrm{a}}$

14

2.8

7.6b

1.8

3

$4.5^{b}$

0.7

5

$9.8^{b}$

0.5

9

(4) Ratio of Actual Exits in (a) to (b) .... (e), corrected for length of period
(5) Actual Number
(6) Expected Number
(7) Ratio of (5) to (6)
(8) Ratio of Actual Exits in corrected for length of period

$\begin{array}{rrrrr}- & 2.7 & 7.6 & 9.8 & 5.1\end{array}$

$\begin{array}{cclll}35 & 16 & 3 & 7 & 3 \\ 13.1 \mathrm{c} & 7.4^{\mathrm{d}} & 4.5^{\mathrm{d}} & 9.7^{\mathrm{d}} & 7^{\mathrm{d}} \\ 2.7 & 2.2 & 0.7 & 0.7 & 0.4\end{array}$

$\begin{array}{lllll}- & 2.2 & 7.0 & 6.5 & 11.7\end{array}$

a Calculated on assumption that all (69) exits in period 1909-1960 were evenly distributed over 51-year period. Rows may not add due to rounding.

b Calculated on assumption that all (31) exits in period 1919-1960 were evenly distributed over 41-year period.

- Calculated on assumption that all (64) exits in period 1909-1958 were evenly distributed over 49 -year period.

d Calculated on assumption that all (29) exits in period 1919-1958 were evenly distributed over 39-year period. 
APPENDIX TABLE II

DISTRIBUTION OF LARGEST FIRMS IN 1919 (EDWARDS LIST) WHICH SURVIVE AS INDEPENDENTS IN 1969, BY INDUSTRY, WITH 1969 COMPANY SALES AND INDUSTRY VALUE OF SHIPMENTS

(Millions of dollars) 2

\begin{tabular}{|c|c|c|c|}
\hline $\begin{array}{l}\text { SIC } 201 \text { (meat) } \\
\text { 1. Swift } \\
\text { 2. Armour } \\
\text { 9. Cudahy }\end{array}$ & $\begin{array}{r}24,878 \\
3,108 \\
2,152 \\
353\end{array}$ & \multirow{2}{*}{\multicolumn{2}{|c|}{$\begin{array}{lr}\text { SIC 281, 282, 286, 287, and } 289 \\
\text { (all other chemicals) } & 34,315 \\
\text { 1. duPont } & 3,655 \\
\text { 2. Union Carbide } & 2,933 \\
\text { 5. W. R. Grace } & 1,792 \\
\text { 7. Allied Chemical } & 1,316\end{array}$}} \\
\hline $\begin{array}{l}\text { SIC } 202 \text { (dairy products) } \\
\text { 2. Borden }\end{array}$ & $\begin{array}{r}13,445 \\
1,740\end{array}$ & & \\
\hline $\begin{array}{l}\text { SIC 203(canned and preserved } \\
\text { foods) } \\
\text { 7. Libby, McNeill and Libby }\end{array}$ & $\begin{array}{r}10,705 \\
346\end{array}$ & \multirow{4}{*}{$\begin{array}{l}\text { SIC 29(petroleum) } \\
\text { 1. Standard Oil (N.J.) } \\
\text { 2. Mobil Oil } \\
\text { 3. Texaco } \\
\text { 4. Gulf Oil } \\
\text { 5. Standard Oil (Calif.) } \\
\text { 6. Standard Oil (Ind.) } \\
\text { 8. Atlantic Richfield } \\
\text { 11. Union Oil (Calif.) } \\
\text { 14. Getty Oil } \\
\text { 18. Ohio Oil (Marathon) }\end{array}$} & \multirow{4}{*}{$\begin{array}{r}24,411 \\
17,538 \\
6,621 \\
5,868 \\
4,953 \\
3,825 \\
3,469 \\
2,691 \\
1,660 \\
1,140 \\
924\end{array}$} \\
\hline $\begin{array}{l}\text { 204(grain mill products) } \\
\text { 2. Corn Products Refining } \\
\text { (CPC International) }\end{array}$ & $\begin{array}{r}10,390 \\
1,218\end{array}$ & & \\
\hline $\begin{array}{l}\text { SIC 205(bakery products) } \\
\text { 2. National Biscuit }\end{array}$ & $\begin{array}{r}7,040 \\
726\end{array}$ & & \\
\hline IIC 206(sugar) & 2,469 & & \\
\hline $\begin{array}{l}\text { 2. Great Western Sugar } \\
\text { 8. Cuban Amer. Sugar } \\
\text { (No. Am.) }\end{array}$ & $\begin{array}{l}486 \\
269\end{array}$ & \multirow{2}{*}{$\begin{array}{l}\text { SIC } 30 \text { (rubber) } \\
\text { 1. Goodyear } \\
\text { 2. Firestone } \\
\text { 3. U.S. Rubber (Uniroyal) } \\
\text { 4. B. F. Goodrich }\end{array}$} & \multirow{2}{*}{$\begin{array}{r}15,728 \\
3,215 \\
2,279 \\
1,554 \\
1,229\end{array}$} \\
\hline $\begin{array}{l}\text { IC 208(beverages) } \\
\text { 4. National Distillers and }\end{array}$ & 11,090 & & \\
\hline & 700 & $\begin{array}{l}\text { SIC } 31 \text { (leather) } \\
\text { none }\end{array}$ & 5,561 \\
\hline $\begin{array}{l}\text { IC } 207 \text { (confectionary) and } \\
209 \text { (misc. foods) } \\
\text { none }\end{array}$ & 13,507 & $\begin{array}{l}\text { SIC } 32 \text { (stone, clay, glass) } \\
\text { none }\end{array}$ & 17,075 \\
\hline $\begin{array}{l}\text { IC 21(tobacco) } \\
\text { 1. R. J. Reynolds } \\
\text { 2. American Tobacco } \\
\text { 4. Ligget and Myers }\end{array}$ & $\begin{array}{r}5,151 \\
1,575 \\
1,361 \\
489\end{array}$ & \multirow{4}{*}{$\begin{array}{l}\text { SIC 331(basic steel) and } \\
\text { 332(iron and steel } \\
\text { foundries) } \\
\text { 1. U.S. Steel } \\
\text { 2. Bethlehem Steel } \\
\text { 4. Republic Steel } \\
\text { 5. National Steel } \\
\text { 6. Inland Steel } \\
\text { 7. Jones and Laughlin } \\
\text { 8. Lykes Youngstown } \\
\text { 10. Wheeling Steel }\end{array}$} & $\begin{array}{r}26,345 \\
4,754\end{array}$ \\
\hline $\begin{array}{l}\text { IC } 22 \text { (textiles) } \\
\text { none }\end{array}$ & 23,112 & & $\begin{array}{l}2,928 \\
1,500 \\
1,225\end{array}$ \\
\hline $\begin{array}{l}\text { IC } 23 \text { (apparel) } \\
\text { none }\end{array}$ & 24,250 & & $\begin{array}{l}1,216 \\
1,062\end{array}$ \\
\hline $\begin{array}{l}\text { IC 24(lumber) and } \\
26 \text { (paper and pulp) }\end{array}$ & 38,083 & & 928 \\
\hline $\begin{array}{l}\text { 1. International Paper } \\
\text { 4. Weyerhauser }\end{array}$ & $\begin{array}{l}1,777 \\
1,239\end{array}$ & \multirow{5}{*}{$\begin{array}{l}\text { SIC 333, 334, 335, 336, and } \\
\text { 339(all other basic metal } \\
\text { work) } \\
\text { 1. Aluminum Corp. of Amer. } \\
\text { 2. Anaconda } \\
\text { 3. Kennecott } \\
\text { 6. National Lead } \\
\text { 7. American Smelting \& } \\
\text { Refining } \\
\text { [8] Internat'l. Nickel of Canada } \\
\text { 8. Phelps Dodge } \\
\text { 23. U.S. Smelting, Mining } \\
\text { \& Refining }\end{array}$} & \\
\hline $\begin{array}{l}\text { IC } 25 \text { (furniture) } \\
\text { none }\end{array}$ & 9,251 & & $\begin{array}{r}23,786 \\
1,545\end{array}$ \\
\hline $\begin{array}{l}\text { SIC } 27 \text { (printing and } \\
\text { publishing) } \\
\text { none }\end{array}$ & 25,068 & & $\begin{array}{r}1,411 \\
1,050 \\
930\end{array}$ \\
\hline $\begin{array}{l}\text { IC } 283 \text { (drugs) } \\
\text { none }\end{array}$ & 6,228 & & $\begin{array}{l}771 \\
684\end{array}$ \\
\hline $\begin{array}{l}\text { IC 284(soaps and toilet } \\
\text { articles) } \\
\text { 1. Procter and Gamble }\end{array}$ & $\begin{array}{l}7,620 \\
2,708\end{array}$ & & 672 \\
\hline
\end{tabular}


APPENDIX TABLE II (Continued)

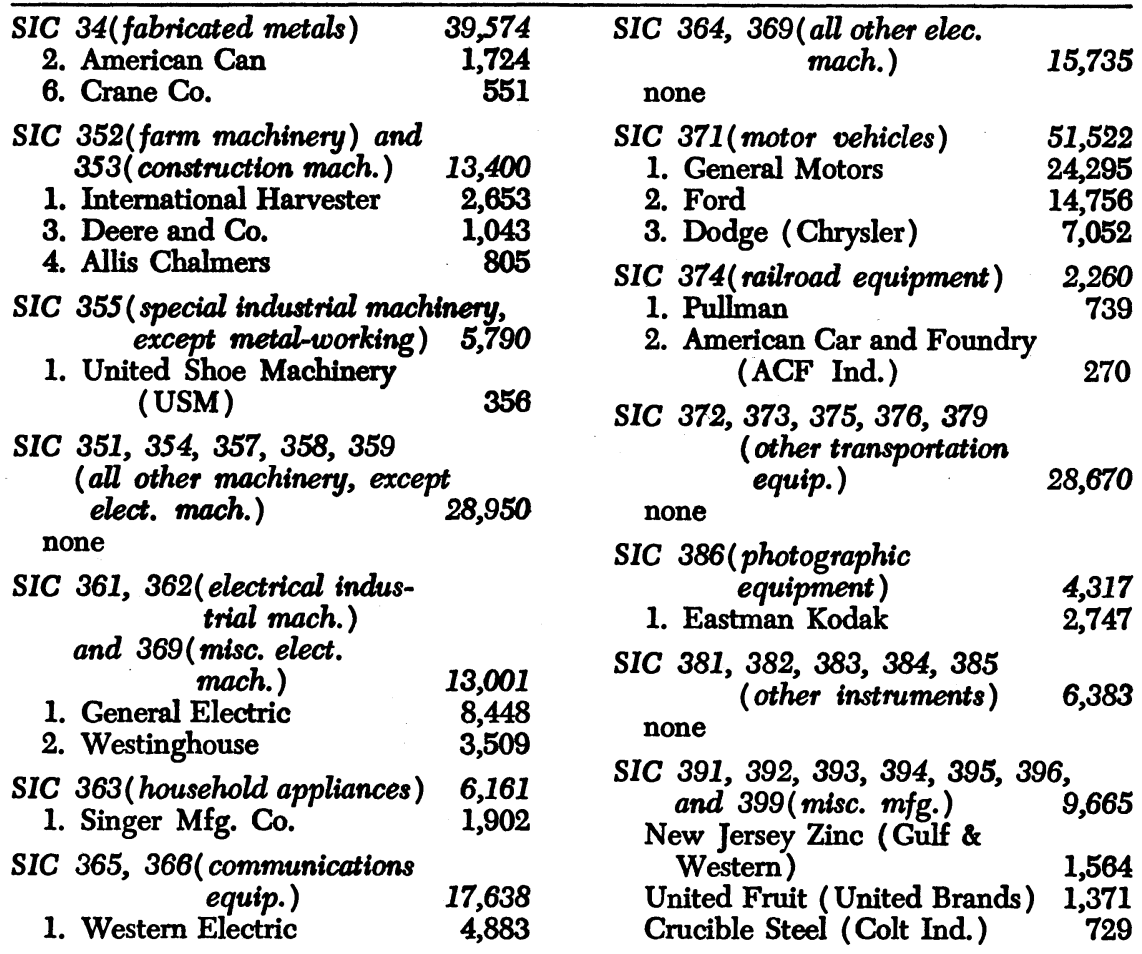

a The total sales for all companies in an industry may exceed the industry's total "value of shipments" since company sales figures include foreign sales and sales in other industries.

Sources: Industry "value of shipments" taken from U.S. Bureau of the Census, Annual Survey of Manufactures, 1969, General Statistics for Industry Groups and Industries, M69(AS)-1 (Washington, D.C.: U.S. Government Printing Office, 1971), Table 1; sales for individual companies taken from Fortune magazine, "The 500 Largest Industrial Corporations" (May 1970), and Moody's Industrial Manual, 1971 (New York: Moody's Investor Service, 1971); rank within industry calculated from News Front magazine, "The 1000 Leading U.S. Manufactures" (Midsummer 1970). 


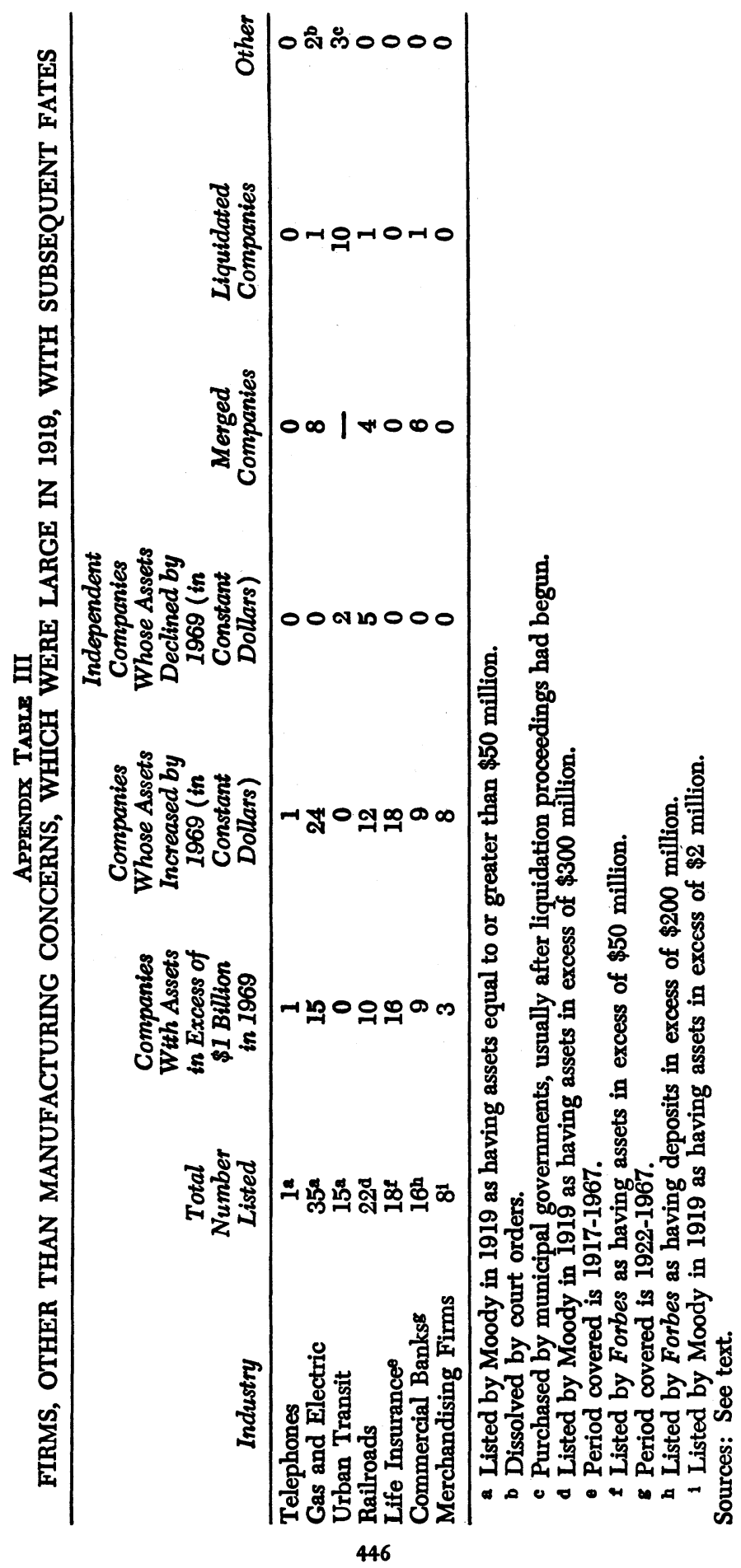


APPENDIX TabLE IV

LARGE INDUSTRIALS IN 1903

FIRMS WITH 1903 ASSETS EXCEEDING \$15 MILLION

\begin{tabular}{|c|c|c|c|c|}
\hline $\begin{array}{r}1 \\
A \\
(M \\
0\end{array}$ & $\begin{array}{l}1903 \\
\text { Assets } \\
\text { Millions } \\
\text { of } \$ \text { ) }\end{array}$ & $\begin{array}{c}1917 \\
\text { Assets } \\
\text { (Millions } \\
\text { of } \$ \text { ) }\end{array}$ & $\begin{array}{c}1917 \\
\text { Name if } \\
\text { Different }\end{array}$ & $\begin{array}{c}\text { Date and Nature } \\
\text { of End as } \\
\text { Independent }\end{array}$ \\
\hline $\begin{array}{l}\text { U.S. Steel } \\
\text { Consolidated Tobacco }\end{array}$ & $\begin{array}{r}1,547 \\
187\end{array}$ & $\begin{array}{r}2,450 \\
164\end{array}$ & Amer. Tobacco & $\begin{array}{l}\text { (1911 divided into } \\
16 \text { cos.) }\end{array}$ \\
\hline $\begin{array}{l}\text { Intl. Mercantile Marine } \\
\text { Amalgamated Copper } \\
\text { U.S. Leather } \\
\text { American Sugar Ref. } \\
\text { Intl. Harvester } \\
\text { Amer. Smelt. \& Ref. }\end{array}$ & $\begin{array}{l}170 \\
155 \\
141 \\
126 \\
120 \\
100\end{array}$ & $\begin{array}{l}204 \\
226 \\
145 \\
137 \\
265 \\
222\end{array}$ & $\begin{array}{l}\text { Anaconda } \\
\text { Central Leather }\end{array}$ & \\
\hline $\begin{array}{l}\text { Consolidated Lake } \\
\text { Superior } \\
\text { Standard Oil }\end{array}$ & $\begin{array}{l}98 \\
98\end{array}$ & $\begin{array}{r}49 \\
574\end{array}$ & $\begin{array}{l}\text { Lake Superior } \\
\text { Corp. }\end{array}$ & $\begin{array}{l}\text { (1911 divided into } \\
34 \text { cos.) }\end{array}$ \\
\hline $\begin{array}{l}\text { Distillers Securities } \\
\text { American Can } \\
\text { Corn Products Ref. } \\
\text { Pullman } \\
\text { U.S. Shipbuilding } \\
\text { American Woolen } \\
\text { National Biscuit } \\
\text { Amer. Car \& Foundry } \\
\text { Pittsburgh Coal } \\
\text { U.S. Realty Construction }\end{array}$ & $\begin{array}{l}90 \\
81 \\
80 \\
74 \\
73 \\
69 \\
61 \\
60 \\
60 \\
60\end{array}$ & $\begin{array}{r}56 \\
133 \\
112 \\
143 \\
382 \\
123 \\
74 \\
127 \\
113 \\
32\end{array}$ & $\begin{array}{l}\text { U.S. Realty \& Im- } \\
\text { provement }\end{array}$ & \\
\hline $\begin{array}{l}\text { U.S. Rubber } \\
\text { International Paper } \\
\text { Republic Iron \& Steel } \\
\text { Crucible Steel } \\
\text { Virginia-Carolina Chem. } \\
\text { Amer. Locomotive }\end{array}$ & $\begin{array}{l}59 \\
59 \\
56 \\
55 \\
53 \\
50\end{array}$ & $\begin{array}{r}258 \\
78 \\
122 \\
90 \\
94 \\
84\end{array}$ & & \\
\hline $\begin{array}{l}\text { United Copper } \\
\text { Swift } \\
\text { Lackawanna Steel }\end{array}$ & $\begin{array}{l}\mathbf{5 0} \\
\mathbf{5 0} \\
\mathbf{5 0}\end{array}$ & $\begin{array}{l}3 \overline{306} \\
117\end{array}$ & & 1913 liquidated \\
\hline Cambria Steel & 45 & - & & $\begin{array}{l}1916 \text { acq. by Mid- } \\
\text { vale Steel }\end{array}$ \\
\hline $\begin{array}{l}\text { American Writing Paper } \\
\text { General Electric }\end{array}$ & $\begin{array}{l}42 \\
42\end{array}$ & $\begin{array}{r}41 \\
232\end{array}$ & & \\
\hline Monongahela River Coal & 40 & - & & $\begin{array}{l}1914 \text { acq. by Pitts- } \\
\text { burgh Coal }\end{array}$ \\
\hline $\begin{array}{l}\text { Intl. Salt } \\
\text { Pressed Steel Car }\end{array}$ & $\begin{array}{l}38 \\
37\end{array}$ & $\begin{array}{l}12 \\
45\end{array}$ & & \\
\hline $\begin{array}{l}\text { American Bicycle } \\
\text { American Ice } \\
\text { Amer. Agric. Chemical }\end{array}$ & $\begin{array}{l}37 \\
36 \\
35\end{array}$ & $\begin{array}{l}\overline{35} \\
83\end{array}$ & & 1915 bankrupt \\
\hline Pennsylvania Steel & 34 & - & & $\begin{array}{l}1916 \text { acq. by } \\
\text { Bethlehem }\end{array}$ \\
\hline $\begin{array}{l}\text { Lehigh Coal \& Navigation } \\
\text { International Nickel }\end{array}$ & $\begin{array}{l}34 \\
34\end{array}$ & $\begin{array}{l}81 \\
63\end{array}$ & & \\
\hline
\end{tabular}




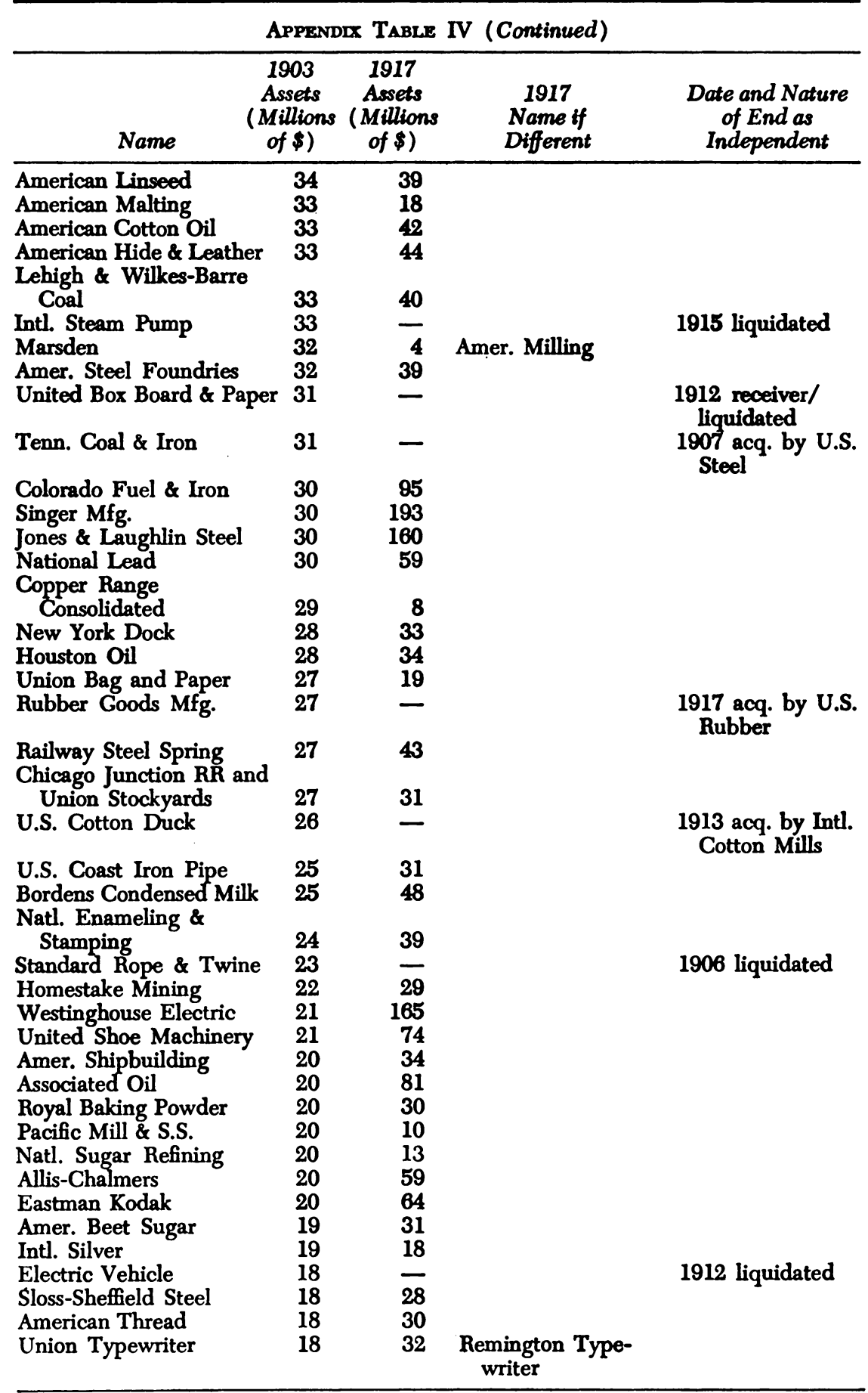




\begin{tabular}{|c|c|c|c|c|}
\hline \multicolumn{5}{|c|}{ APPENDEX TABLE IV (Continued) } \\
\hline $\begin{array}{r}I \\
A \\
\langle M \\
0\end{array}$ & $\begin{array}{l}1903 \\
\text { Assets } \\
\text { Millions } \\
\text { of } \$ \text { ) }\end{array}$ & $\begin{array}{c}1917 \\
\text { Assets } \\
\text { (Millions } \\
\text { of } \$ \text { ) }\end{array}$ & $\begin{array}{l}1917 \\
\text { Name if } \\
\text { Different }\end{array}$ & $\begin{array}{l}\text { Date and Nature } \\
\text { of End as } \\
\text { Independent }\end{array}$ \\
\hline Fairmont Coal & 18 & 一 & & $\begin{array}{l}1912 \text { acq. by Con- } \\
\text { solidation Coal }\end{array}$ \\
\hline $\begin{array}{l}\text { American Express } \\
\text { Central Foundry } \\
\text { Virginia }\end{array}$ & $\begin{array}{l}18 \\
18\end{array}$ & $\begin{array}{l}59 \\
11\end{array}$ & & \\
\hline $\begin{array}{l}\text { Vurginia Iron, Coal, } \\
\text { \& Coke } \\
\text { Standard Milling }\end{array}$ & $\begin{array}{l}17 \\
17\end{array}$ & $\begin{array}{l}16 \\
29\end{array}$ & & \\
\hline $\begin{array}{l}\text { Consol. Ry. Lighting and } \\
\text { Refrigeration }\end{array}$ & 17 & - & & 1909 liquidated \\
\hline General Chemical & 17 & 57 & $\begin{array}{l}\text { Allied Chemical \& } \\
\text { Dye }\end{array}$ & \\
\hline $\begin{array}{l}\text { Pacific Coast Co. } \\
\text { Brooklyn Ferry of N.Y. }\end{array}$ & $\begin{array}{l}17 \\
17\end{array}$ & 24 & & 1908 liquidated \\
\hline Kirby Lumber & 16 & $\overline{17}$ & & 1000 मq \\
\hline United Fruit & 16 & 110 & & \\
\hline Electric Storage Battery & 16 & 25 & & \\
\hline Armour & 16 & 314 & & \\
\hline $\begin{array}{l}\text { New England Cotton Yam } \\
\text { Newport News Shipbuild- }\end{array}$ & 16 & 8 & & \\
\hline ing and Drydock & 15 & 31 & & \\
\hline Pacific Packing \& Navig. & 15 & - & & 1904 liquidated \\
\hline Diamond Match & 15 & 22 & & \\
\hline
\end{tabular}

Source: See text. 
APPENDIX TABLE $V$

LARGE COMPANIES IN 1919

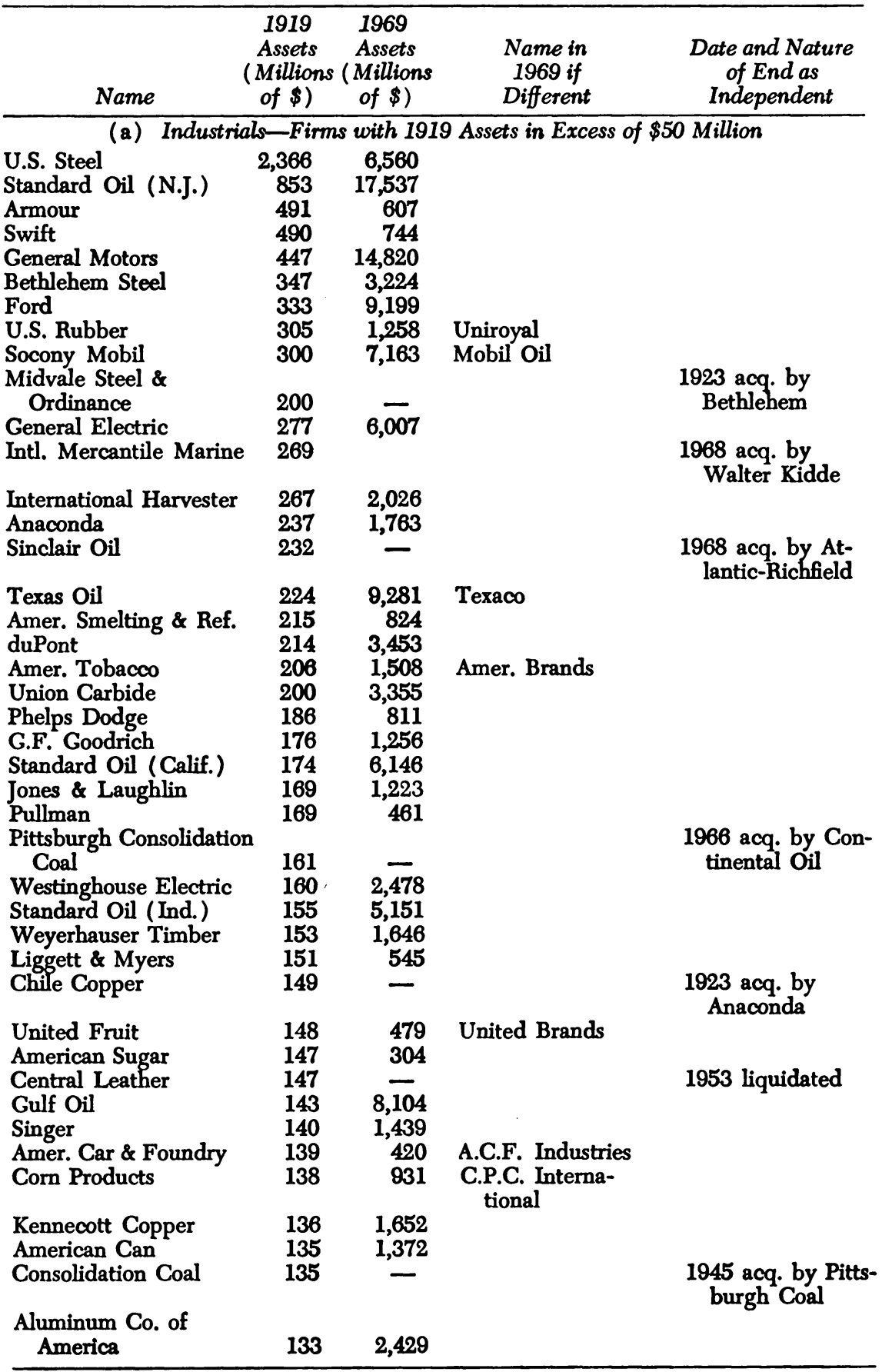




\begin{tabular}{|c|c|c|c|c|}
\hline \multicolumn{5}{|c|}{ APPENDIX TABLE V (Continued) } \\
\hline Name & $\begin{array}{c}1919 \\
\text { Assets } \\
\text { (Millions } \\
\text { of } \$ \text { ) }\end{array}$ & $\begin{array}{c}1969 \\
\text { Assets } \\
\text { (Millions } \\
\text { of } \$ \text { ) }\end{array}$ & $\begin{array}{l}\text { Name in } \\
1969 \text { if } \\
\text { Different }\end{array}$ & $\begin{array}{c}\text { Date and Nature } \\
\text { of End as } \\
\text { Independent }\end{array}$ \\
\hline American Woolen & 133 & - & & $\begin{array}{l}1955 \text { acq. by } \\
\text { Textron }\end{array}$ \\
\hline $\begin{array}{l}\text { Ohio Cities Service } \\
\text { (Pure) }\end{array}$ & 132 & - & & $\begin{array}{l}1965 \text { acq. by } \\
\text { Union Oil }\end{array}$ \\
\hline Prairie Oil \& Gas & 130 & 二 & & $\begin{array}{l}1932 \text { acq. by Sin- } \\
\text { clair }\end{array}$ \\
\hline Crucible Steel & 127 & 588 & Colt Industries & \\
\hline Wilson & 127 & - & & $\begin{array}{l}1967 \text { acq. by Ling- } \\
\text { Temco-Vought }\end{array}$ \\
\hline Republic Steel & 126 & 1,782 & & \\
\hline $\begin{array}{l}\text { Virginia-Carolina } \\
\text { Chemical }\end{array}$ & 121 & - & & $\begin{array}{l}1962 \text { acq. by Mobil } \\
\text { Oil }\end{array}$ \\
\hline Willys-Overland & 113 & - & & $\begin{array}{l}1953 \text { acq. by } \\
\text { Kaiser }\end{array}$ \\
\hline $\begin{array}{l}\text { Wheeling Steel } \\
\text { Goodyear Tire }\end{array}$ & $\begin{array}{l}113 \\
113\end{array}$ & $\begin{array}{r}617 \\
2,763\end{array}$ & & \\
\hline Amer. Agric. Chem. & 111 & - & & $\begin{array}{l}1963 \text { acq. by Con- } \\
\text { tinental Oil }\end{array}$ \\
\hline Cuba Cane Sugar & 110 & - & & 1958 liquidated \\
\hline Tube & 109 & 1,402 & Lykes-Youngstown & \\
\hline Western Electric & 108 & 3,172 & & \\
\hline Morris & 103 & - & & $\begin{array}{l}1923 \text { acq. by } \\
\text { Armour }\end{array}$ \\
\hline R. J. Reynolds & 103 & 1,693 & & \\
\hline Philadelphia \& Reading & 100 & - & & $\begin{array}{l}1968 \text { acq. by } \\
\text { Northwest }\end{array}$ \\
\hline Calumet and Hecla & 100 & - & & $\begin{array}{l}1968 \text { acq. by Uni- } \\
\text { versal Oil }\end{array}$ \\
\hline $\begin{array}{l}\text { Atlantic Gulf and West } \\
\text { Indies S.S.L. }\end{array}$ & 99 & - & & 1953 liquidated \\
\hline W. R. Grace & 97 & 1,541 & & \\
\hline Lackawana Steel & 95 & - & & $\begin{array}{l}1923 \text { acq. by } \\
\text { Bethlehem }\end{array}$ \\
\hline Atlantic Refining & 95 & 4,235 & Atlantic-Richfield & \\
\hline $\begin{array}{l}\text { Proctor and Gamble } \\
\text { Amer. Locomotive }\end{array}$ & $\begin{array}{l}94 \\
93\end{array}$ & 1,692 & & 1964 liquidated \\
\hline Cudahy Packing & 92 & 72 & & \\
\hline Steel \& Tube & 92 & - & & $\begin{array}{l}1923 \text { acq. by } \\
\text { Youngstown } \\
\text { S. \& T. }\end{array}$ \\
\hline $\begin{array}{l}\text { Union Oil of Calif. } \\
\text { Eastman Kodak }\end{array}$ & $\begin{array}{l}80 \\
89\end{array}$ & 2,476 & & \\
\hline P. Lorillard & 88 & - & & $\begin{array}{l}1968 \text { acq. by } \\
\text { Loews }\end{array}$ \\
\hline Pan-American Pet. & 88 & 一 & & $\begin{array}{l}1929 \text { acq. by St. } \\
\text { Oil (Ind.) }\end{array}$ \\
\hline Studebaker & 88 & - & & $\begin{array}{l}1967 \text { acq. by Wor- } \\
\text { thington }\end{array}$ \\
\hline $\begin{array}{l}\text { National Lead } \\
\text { International Paper } \\
\text { Lehigh Coal \& Nav. }\end{array}$ & $\begin{array}{l}88 \\
86 \\
85\end{array}$ & $\begin{array}{r}695 \\
1,887 \\
-\end{array}$ & & 1965 liquidated \\
\hline
\end{tabular}




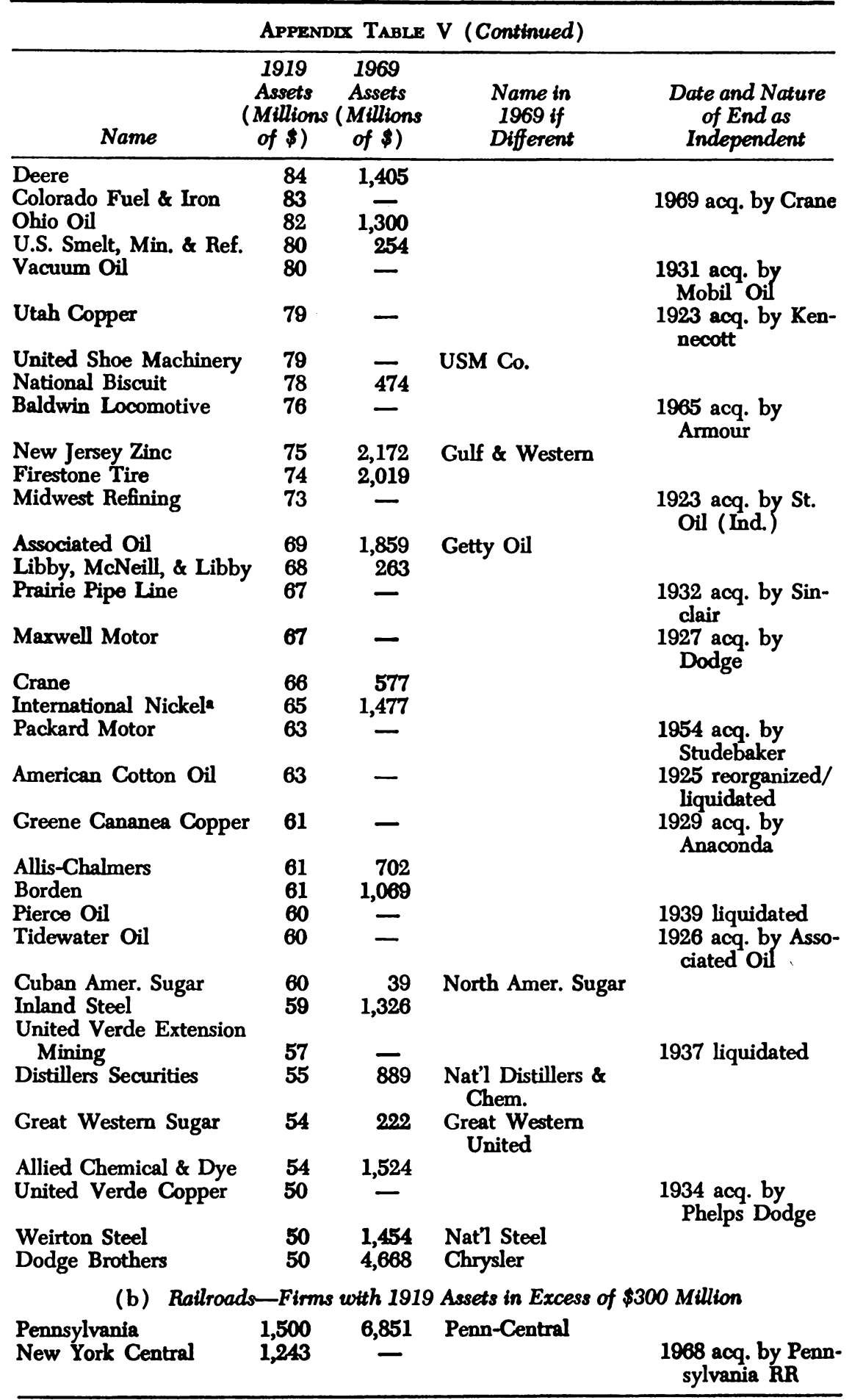




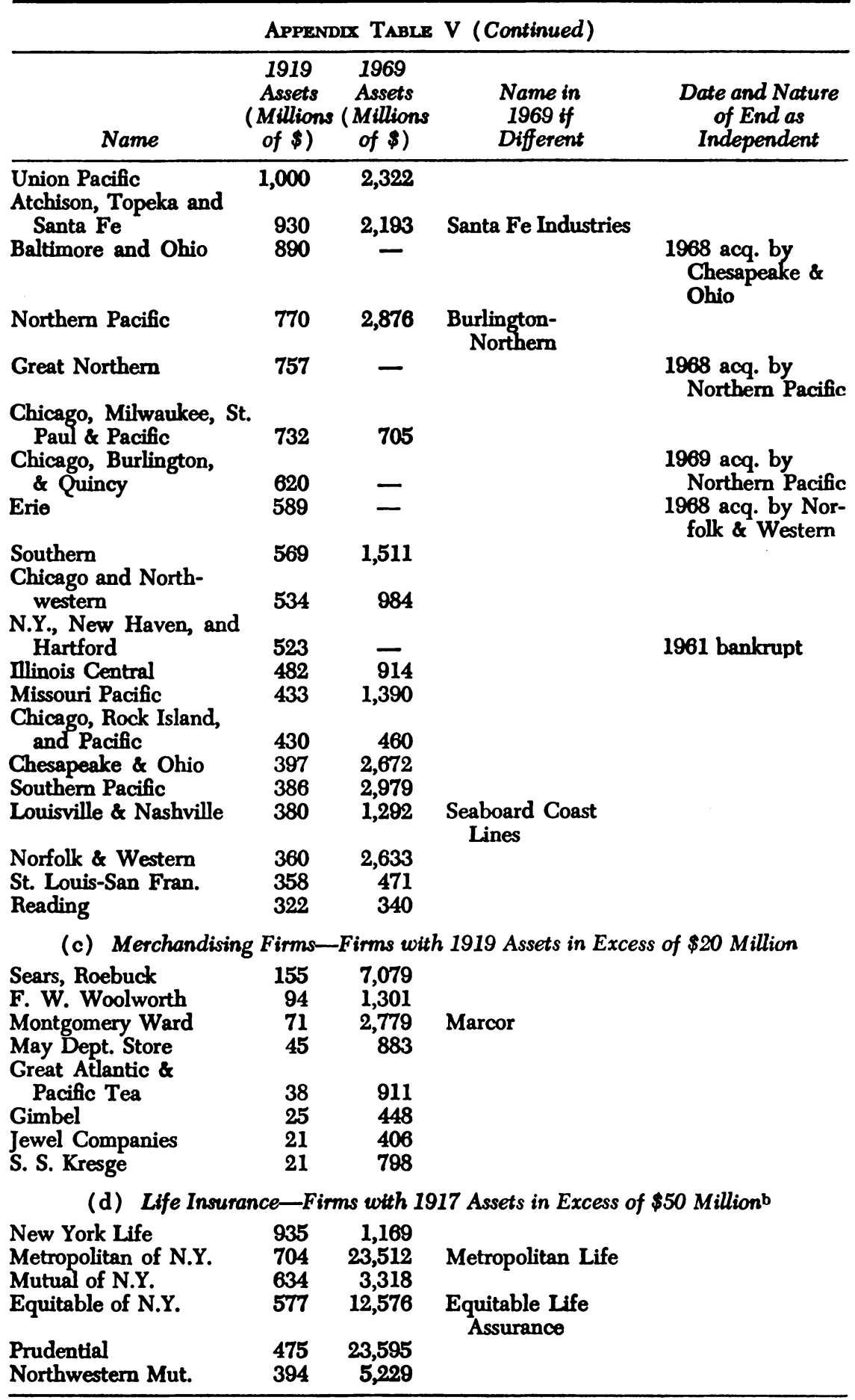




\begin{tabular}{|c|c|c|c|c|}
\hline \multicolumn{5}{|c|}{ APPENDIX TabLE V (Continued) } \\
\hline Name & $\begin{array}{c}1919 \\
\text { Assets } \\
\text { (Millions } \\
\text { of } \$ \text { ) }\end{array}$ & $\begin{array}{c}1969 \\
\text { Assets } \\
\text { (Millions } \\
\text { of } \$ \text { ) }\end{array}$ & $\begin{array}{l}\text { Name in } \\
1969 \text { if } \\
\text { Different }\end{array}$ & $\begin{array}{c}\text { Date and Nature } \\
\text { of End as } \\
\text { Independent }\end{array}$ \\
\hline $\begin{array}{l}\text { Mutual Benefit (N.J.) } \\
\text { Penn Mutual } \\
\text { John Hancock } \\
\text { Aetna Life } \\
\text { Travelers } \\
\text { Union Central of Ohio } \\
\text { Mass. Mutual } \\
\text { New England Mutual } \\
\text { Connecticut Mutual } \\
\text { National Life of Vt. } \\
\text { Guardian Life } \\
\text { State Mutual of Mass. }\end{array}$ & $\begin{array}{r}219 \\
183 \\
156 \\
141 \\
129 \\
121 \\
101 \\
85 \\
80 \\
69 \\
55 \\
55\end{array}$ & $\begin{array}{r}2,257 \\
2,203 \\
8,380 \\
7,330 \\
5,460 \\
881 \\
3,436 \\
2,981 \\
2,250 \\
1,247 \\
781 \\
1,087\end{array}$ & New England Life & \\
\hline
\end{tabular}

(e) Banks-Firms with 1922 Deposits in Excess of $\$ 200$ Millione

National City Bank, N.Y. $757 \quad 12,940 \quad$ First National

Guaranty Trust Co., N.Y. $492 \quad 6,445 \quad$ Morgan Guaranty

Chase National Bank, N.Y. 466 Trust, N.Y.

National Bank of $427 \quad-$

Chase Manhattan, Commerce, N.Y.

Continental and Commercial Bank, Chicago

Continental Illinois

1929 acq. by Morgan Guarantee Trust

First National Bank, N.Y. 325 National Bank and Trust, Chicago

Bankers Trust, N.Y. $\quad 312 \quad 5,094$

Equitable Trust, N.Y. 271

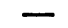

Irving National Bank, N.Y.

Irving Trust

1955 acq. by First National City, N.Y.

Mechanics and Metals Nat'l Bank, N.Y.

Bank of Manhattan, N.Y. 240

Central Union Trust, N.Y. 1930 acq. by Chase Manhattan

First National Bank, Chicago

Bank of Italy, San Francisco

Union Trust Co., Cleveland

Corn Exchange Bank, N.Y.

Bank of America, San Francisco
Manufacturers

Hanover Trust, N.Y.

1926 acq. by Chase Manhattan

1955 acq. by Chase Manhattan

(f) Utilities Except Urban Transit-Firms with 1919 Assets in Excess of $\$ 50$ Million American Tel. \& Tel. $\quad 1,530 \quad 43,903$ 


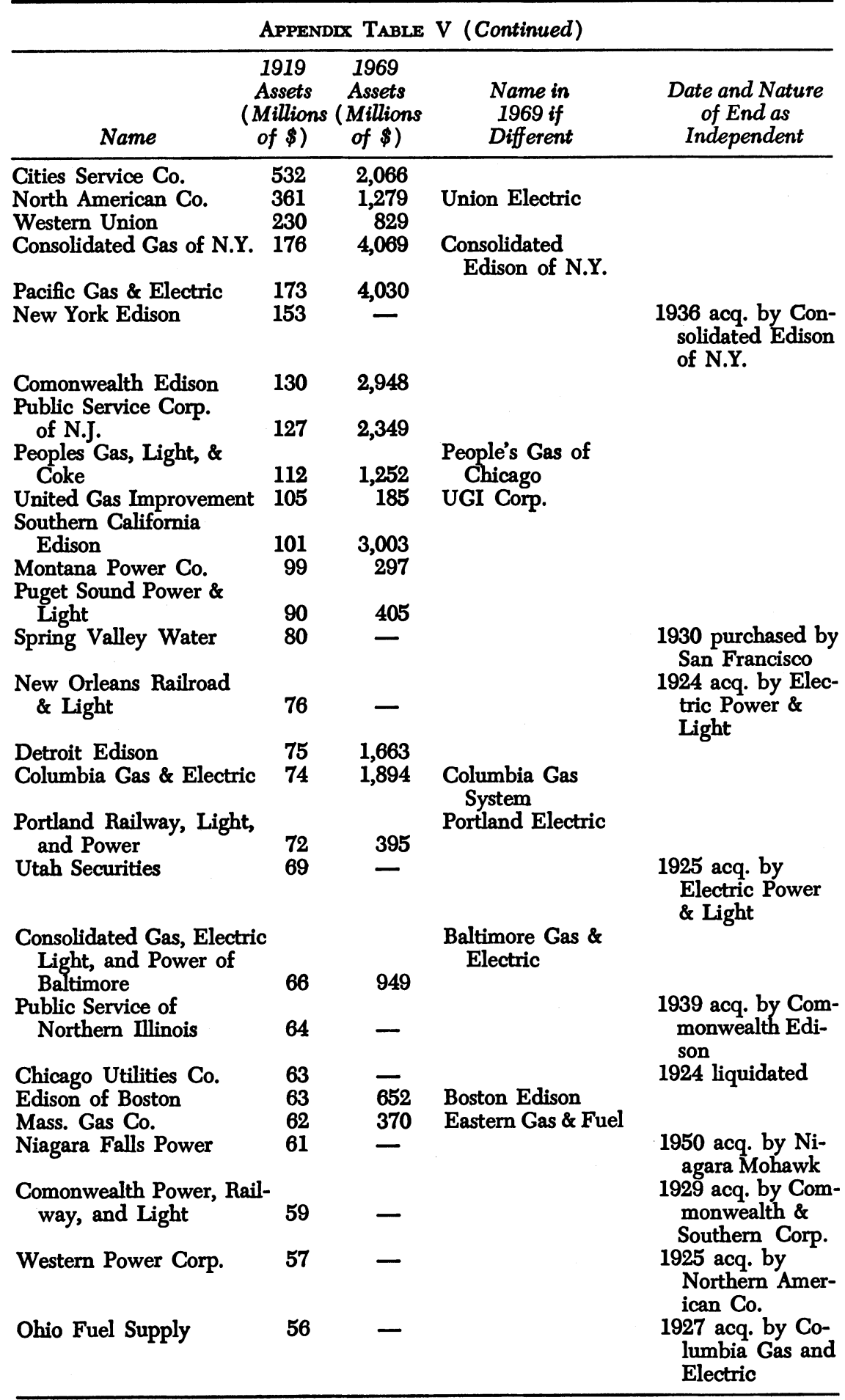




\begin{tabular}{|c|c|c|c|c|}
\hline \multicolumn{5}{|c|}{ APPENDIX TABLE V (Continued) } \\
\hline Name & $\begin{array}{l}1919 \\
\text { Assets } \\
\text { Millions } \\
\text { of } \$)\end{array}$ & $\begin{array}{c}1969 \\
\text { Assets } \\
\text { (Millions } \\
\text { of } \$ \text { ) }\end{array}$ & $\begin{array}{l}\text { Name in } \\
1969 \text { if } \\
\text { Different }\end{array}$ & $\begin{array}{c}\text { Date and Nature } \\
\text { of End as } \\
\text { Independent }\end{array}$ \\
\hline Brooklyn Union Gas & 56 & 332 & & \\
\hline American Water Works & 55 & $\begin{array}{r}1,091 \\
659\end{array}$ & $\begin{array}{l}\text { Allegheny Power } \\
\text { American Water } \\
\text { Works }\end{array}$ & $\begin{array}{l}\text { original company } \\
\text { divided by court } \\
\text { order }\end{array}$ \\
\hline United Light \& Railway & 54 & 一 & & $\begin{array}{l}1950 \text { dissolved by } \\
\text { court order }\end{array}$ \\
\hline $\begin{array}{l}\text { Georgia Railroad and } \\
\text { Power }\end{array}$ & 53 & 2,738 & $\begin{array}{l}\text { The Southern } \\
\text { Company }\end{array}$ & \\
\hline Virginia Railroad and & & & Virginia Electric & \\
\hline Power & 53 & 1,531 & and Power & \\
\hline $\begin{array}{l}\text { Consumers Power } \\
\text { American Light \& }\end{array}$ & 52 & 1,811 & American Natural & \\
\hline Traction & 51 & 1,557 & Gas & \\
\hline Brooklyn Edison & 50 & - & & $\begin{array}{l}1928 \text { acq. by Con- } \\
\text { solidated Edison }\end{array}$ \\
\hline Mississippi River Power & 50 & 一 & & $\begin{array}{l}1925 \text { acq. by } \\
\text { North American } \\
\text { Co. }\end{array}$ \\
\hline \multicolumn{5}{|c|}{ (g) Urban Transit Companies-Firms with Assets in Excess of $\$ 50$ Million } \\
\hline Brooklyn Rapid Transit & 223 & - & Hudson Rapid & 1944 dissolved \\
\hline RR & 128 & 53 & Tubes & \\
\hline Interborough Consolidated & & & & \\
\hline $\begin{array}{l}\text { Corporation } \\
\text { Philadelphia Rapid }\end{array}$ & 126 & - & & 1923 liquidated \\
\hline Transit & 123 & 一 & & 1968 liquidated \\
\hline Chicago Railway & & & & \\
\hline $\begin{array}{l}\text { Company } \\
\text { United Railway and }\end{array}$ & 114 & - & & 1946 bankrupt \\
\hline $\begin{array}{l}\text { United Kallway and } \\
\text { Electric (Baltimore) }\end{array}$ & 92 & 一 & & 1935 liquidated \\
\hline Third Avenue Railway & 79 & - & & $\begin{array}{l}1962 \text { acq. by New } \\
\text { York }\end{array}$ \\
\hline Boston Elevated & 76 & 一 & & $\begin{array}{l}1947 \text { acq. by } \\
\text { Boston }\end{array}$ \\
\hline $\begin{array}{l}\text { N.Y. Consolidated } \\
\text { Railroad }\end{array}$ & 65 & - & & $\begin{array}{l}1942 \text { acq. by New } \\
\text { York }\end{array}$ \\
\hline $\begin{array}{l}\text { United Railway Invest- } \\
\text { ment Co. }\end{array}$ & & & & \\
\hline Detroit United Railway & $\begin{array}{l}00 \\
64\end{array}$ & 二 & & 1928 liquidated \\
\hline New York State Railway & 62 & - & & 1967 liquidated \\
\hline Twin City Rapid Transit & 58 & 24 & MEI Corp. & \\
\hline $\begin{array}{l}\text { Chicago City Railway } \\
\text { Chicago Elevated Railroac }\end{array}$ & $\begin{array}{r}55 \\
51\end{array}$ & - & & $\begin{array}{l}1946 \text { bankrupt } \\
1946 \text { bankrupt }\end{array}$ \\
\hline
\end{tabular}

a International Nickel, incorporated in New Jersey, was the parent of International Nickel of Canada, Ltd., until 1928.

b Period covered is 1917 to 1967.

c Figures given are for deposits, not total assets; period covered is 1922 to 1967.

Source: See text. 
APPENDIX Table VI

PRICES USED IN PRICE CORRECTIONS OF ASSET BASES:

"WHOLESALE PRICES, ALL COMMODITIES"

\begin{tabular}{|c|c|c|c|}
\hline \multicolumn{2}{|c|}{ Early Period } & & \\
\hline 1900 & 56.1 & & \\
\hline 1903 & 59.6 & & \\
\hline 1909 & 67.6 & BASE: & $1926=100$ \\
\hline 1917 & 117.5 & & \\
\hline 1947 & 152.1 & & \\
\hline
\end{tabular}

\section{Later Period}

\begin{tabular}{|c|c|c|c|}
\hline $\begin{array}{l}1917 \\
1919 \\
1958 \\
1960 \\
1967 \\
1969\end{array}$ & $\begin{array}{r}60.6 \\
71.4 \\
94.6 \\
94.9 \\
100.0 \\
106.5\end{array}$ & BASE: & $1967=100$ \\
\hline
\end{tabular}

Sources: Early: Historical Statistics of the U.S., Table E13-24, p. 116. Later: Statistical Abstract of the United States, 1972, U.S. Department of Commerce (Washington: Government Printing Office, 1973), Table No. 559, p. 342. The prices for 1917 and 1919 were spliced onto this series using data listed in previous source. 